\title{
Introduction: Critical Scholarship, Practice and Education
}

\section{Harald Bauder}

Ryerson University

\section{Salvatore Engel-DiMauro}

Ryerson University

Please Cite:

Bauder, H., \& Engel-DiMauro, S. (2008). Introduction: Critical scholarship, practice and education. In Critical Geographies: A Collection of Readings (pp. 17). Kelowna, BC: Praxis Press.

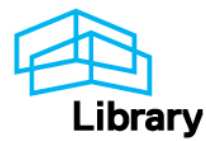




\title{
1 \\ Introduction: \\ Critical Scholarship, Practice and Education
}

\author{
Harald Bauder and Salvatore Engel-Di Mauro ${ }^{1}$
}

"Critical geography" is both an approach to scholarship and a practice of scholarship. The term "critical" refers to a tradition of critical theory. An often cited representative of this tradition is the so-called Frankfurt School. This "school" consisted of a network of researchers affiliated with the Institute for Social Research in Frankfurt, Germany, which operated from 1923 to 1933, moved to New York during the Nazi regime, but reopened in Frankfurt in 1950. Although the label "Frankfurt School" is problematic and inexact (Behrens, 2002), it does permit associating some basic ideas with the notion of "critical". According to Herbert Marcuse (1964: x), a prominent member of this school: "To investigate the roots of [social] developments and examine their historical alternatives is part of the aim of a critical theory, a theory which analyzes society in the light of its used and unused or abused capacities for improving the human condition."

Achieving this aim, however, is complicated by the inability of researchers to assume objective viewpoints and completely dissociate themselves from the social world and the technologies they use. In fact, scholars and scientists as well as the institutions in which they operate are firmly embedded in the social and political world. If scholarship is uncritical towards its social embeddedness, it is prone to reproduce existing social order and inadvertently promote political, social and cultural interests. Critical scholarship therefore does not deny these interests but rather incorporates them into its approach. Critical scholarship addresses the inevitable dilemma of being a social and political activity by focusing on the tension between the existing social and material world and the possibility for changing this world. With this focus, critical scholarship realizes its role in society not to blindly reproduce existing social order, but to create the conditions in which progressive change can occur. This

1 (C) This text is licensed under the http://creativecommons.org/licenses/by-nc-nd/2.5/ca/ Creative Commons No Derivative, No Commercial Use 2.5. Canada License. 
focus also means that the separation between scholarship and practice cannot be maintained. Rather, critical scholarship embraces the connection to critical practice.

In the discipline of Geography, critical scholarship has a long tradition. This tradition, however, has varied considerably based on the places and languagecommunities in which geographical knowledge is produced and geographical education occurs. The still largely 'white', Eurocentric viewpoints that prevail in 'Anglophone' academic geography, as Laura Pulido points out in Chapter 7, reflects its institutional provenance in and spread from central and western Europe. The publications included in this Collection necessarily suffer from this narrow perspective and from the continuing emphasis in 'Anglophone' academia on constructing and drawing from narrow historical and intellectual lineages and selective evidence (see Diop, 1974). Anglophone histories of critical geography still largely ignore the contributions of African, Asian and Latin American knowledge systems and the geographical knowledges developed in other cultures. An example is Chapter 9 by Elisée Reclus, included in this collection. This is a mid- $19^{\text {th }}$ Century work, originally in French, which influenced 'Anglophone' geographers associated with the so-called "New Left" and "radical geography" in the 1960s and 1970s (Peet, 1977). The New Left and radical geography had the great merit of rediscovering and reworking critical approaches from both within and outside geography. However, the main sources of theoretical inspiration came from 'white', male, heterosexual European perspectives ${ }^{2}$. We do not suggest that a critical outlook is impossible through a single or limited cultural framework (Marxist work, for example, has had much applicability beyond white males in Europe and North America). Recently, however, the perspective has been broadened with the development of feminist, sexuality, and postcolonial approaches. These recent approaches, along with earlier radical approaches, have contributed to the emergence of the term "critical geographies" (Gibbons, 2001; Peet, 1998).

Despite the long tradition of critical thinking in Geography, the label of "critical geography" is a rather recent phenomenon. It gained popularity, for example, in Scandinavia in the early 1980s with the establishment of an annual meeting for critical geography. In the United States, an annual mini-conference on critical geography was initiated in 1994. In the United Kingdom, some geographers organized under the label critical geography in the mid-1990s, opposing the sponsorship of the Royal Geographical Society by Shell Oil, a corporation associated with a brutal military regime in Nigeria (Berg, 2002; Blomley, 2008; Watts, 2001). In an effort to foster international linkages, critical geographers have been congregating for the biannual International Conference on Critical Geography since 1997 and met in Canada, South Korea, Hungary, Mexico and India (see Chapter 6).

2 In addition, there is still an uncritical tendency to reproduce Eurocentric knowledge genealogies, often starting in Greece some 2000 years ago (e.g., Gibbons, 2001) or in Britain about 500 years ago (e.g., Johnston, 2003). 
A particular issue, with which critical geographers have been concerned, is the link between geographical scholarship and activism. While some critical geographic research has sought to support activist struggles "on the street", other research has chosen activism as a research topic. In addition, critical geographic scholarship has been concerned with finding ways in which the university and the very nature in which scholarship is practiced can be transformed (Banerjee-Guha, 2002; Blomley, 2008; Castree, 2000; Fuller and Kitchin, 2004; Moss et al., 2002, 3; Peet, 1998).

Today, critical geographies embrace wide-ranging topics, themes and theories. Yet, one can and should distinguish between critical scholarship and "uncritical" scholarship, which may entail critical thinking but otherwise lacks the recognition of subjectivity, self-reflexivity and the awareness of social and political embeddedness (Blomley, 2006). The texts selected in this book belong to this wider range of critical scholarship in the tradition of critical theory that exists within academic geography.

However, the label of critical scholarship is also contested (Katz, 1998). For example, one author, whose work is included in this book, explicitly rejected the label critical geographer and preferred to be called a socialist geographer. Critical scholarship, which follows critical approaches and practice, in fact, reaches far beyond the community that identifies itself as "critical geographers". At the risk of excluding critical audiences that do not embrace the label "critical geographies" and including authors who do not wish to carry this label, we used the term as the title in this Collection because, in our eyes, it represents inclusiveness and reflects the nature of the work published in the book. In addition, we chose the title for strategic reasons, seeking to claim the notion of "critical geographies" for an open-access publication intended to be "owned" by the geographic community before it is appropriated by the corporate publishing industry. Even in selecting a title for this book, we are confronting the problem that critical scholarship and practice are inseparably intertwined. There is no way around it.

In geographical education, the link between scholarship and practice is particularly important. Perhaps the ideas of critical theory translate most directly into practice in the context of education. The core of critical scholarship relates to the ideas developed by enlightenment thinkers in the $18^{\text {th }}$ and $19^{\text {th }}$ Centuries (Behrens 2002). The German philosopher Immanuel Kant, for example, showed that the categories and concepts, which make up the human world, are formed within the human subject itself. To be "critical", in this context, means to explore the origin and the limits of reason (Werlen, 1999, 198). Now, consider Kant's famous quote from 1783 (2008/1783, emphasis in the original):

Enlightenment is a person's release from his self-imposed tutelage. Tutelage is a person's inability to use of one's own reason without guidance from someone else. Self-imposed is this tutelage when its origin does not lie in the lack of reason but in the lack of resolve and courage to use one's reason without guidance from someone else. Sapere 
aude! "Have courage to use your own reason!" - that is the motto of enlightenment. ${ }^{3}$

It is an important objective of critical education to enable students to use their own reason and not uncritically internalize dogma, reproduce existing norms or regurgitate conventional knowledge. Independent thinking and reasoning, however, has to be exercised with caution and discretion, because it harbours the potential to loop back to dogma and convention, and lead to destruction and violence, as illustrated in the catastrophes of Nazism and Stalinism in the $20^{\text {th }}$ Century (Horkheimer and Adorno, 2002/1944).

Another important figure in critical scholarship is Karl Marx, who recognized the role of education and the educator. In 1845, Marx (1969/1845) scribbled eleven theses in response to a book by Ludwig Feuerbach, whom he critiqued for neglecting the influence of human practice and activity on shaping the human world (first thesis). Before arriving at the famous eleventh thesis "The philosophers have only interpreted the world in various ways; the point is to change it," Marx wrote in the third thesis:

The materialist doctrine [followed by Feuerbach] concerning the changing of circumstances and upbringing forgets that circumstances are changed by people and that it is essential to educate the educator him or herself. This doctrine must, therefore, divide society into two parts, one of which is superior to society.

The coincidence of the changing of circumstances and of human activity or self-changing can be conceived and rationally understood only as revolutionary practice.

Scholarship and education are activities that influence the course of history and shape the world. Rather than conveying objective truths about the world from a hypothetical and non-existing vantage point located outside of the world, scholarship and education always occur in a particular geographical context and point in history. They are practical and "revolutionary" activities because they shape the manner in which people understand the world and how people act on the basis of this understanding (see also David Harvey, Chapter 11).

The importance of pedagogy was not lost on geographer and anarchist Peter Kropotkin. In Chapter 2, which he wrote in 1885, he makes several proposals to teach geography in a manner that cultivates a sense of commonality of all people as human beings, belonging to the same species. As part of what would now be called pedagogical activism, Kropotkin insisted that egalitarianism should be practiced in the

${ }^{3}$ Different translations exist of this text, which was originally published in German. We translated Kant's original text (and Marx' text below) in a manner that best reflects, in our eyes, its meaning in the context of this Introduction. 
classroom and that teaching should lead to the development of self-teaching. It was not until the past few decades, however, that such classroom strategies have gained wideranging attention in the educational systems of North America and Europe.

As Kropotkin understood, pedagogical practices are directly connected to one's understanding and practice of geography (Kearns, 2004). But only in the last three decades have English-speaking geographers begun critiquing the objectivity and truth claims assumed in mainstream geography. They have begun recognizing the subjective, persuasive and "poetic" nature of geographical inquiry (e.g. Barnes and Gregory, 1998). For example, geographers who have drawn on the French historian Michel Foucault have made the relationship between knowledge and power a central theme of their scholarly activities. These geographers acknowledge that scientific knowledge, language and our understanding of the everyday world are inseparably intertwined. Contemporary critical geographers generally realize that their work as scientists, their roles as educators and their participation in public life are deeply political. This realization, however, raises questions of what to do and how to use one's abilities (and "reason" as Kant pointed out) to change the world.

The following chapters offer a wide range of answers to these questions. They all engage in some way with the idea that critical scholarship, if unhappy with the circumstances it uncovers, must help create the conditions for progressive change. The chapters of Part I of this Collection are summarized under the rubric "critical reflections." These chapters look inward, focusing on the practices of academic geographers themselves. What might look to outsiders as exercises in navel-gazing, are to critical geographers valuable assessments of their own practices and important discussion on how to rectify undesirable circumstances. The chapters of Part II fall under the label "space and society." These chapters examine geographical perspectives of society, aiming to facilitate social change. Part III features chapters that engage with our relations with the rest of nature, or the environment. A common theme throughout many of these chapters is not to take received ideas about nature or the environment for granted. Rather, these ideas are ideological reflections of the societies in which they occur, often intertwined with practices of social distinction and subordination. Another theme consists in understanding environmental problems as deeply social in character, intimately intertwined with issues of social justice. Finally, the fourth set of chapters represents work on cartography (i.e., map-making) and Geographic Information Systems that shows the impossibility of neutrality and objectivity in representing the Earth's surface.

The four Parts of the book cover a vast thematic and theoretical terrain of geographical knowledge and reflection. Rather than offering a focused overview of a particular body of critical work, this book involves a diverse set of geographical topics, perspectives or approaches. This diversity should illustrate the wide range of problems to which geographers are applying critical scholarship and inspire readers to address geographical problems in fresh and creative ways. It represents a sort of "hypertext", showing multiple ways of understanding and interpreting similar issues and concerns. 
In Roland Barthes's term, hypertext produces "writerly" texts that do not dominate the reader and insist on particular readings, but instead engage the reader as an "author" and insist upon the openness and intertextuality of the text - that is, its openness to other texts and readings (Pickles, Chapter 33,6).

We hope to have reinforced, through this collection, this openness to a variety of critical approaches, as well as the necessary dialogue among these perspectives that promotes the further development of "critical" political ideas.

\section{References}

Banerjee-Guha, Swapna. 2002. Critical geographical praxis: Globalisation and sociospatial disorder. Economic and Political Weekly, 2-9 November, 4504-9.

Barnes, Trevor and Derek Gregory (eds.). 1998. Reading Human Geography: The Poetics and Politics of Inquiry. London: Arnold.

Behrens, Roger. 2002. Kritische Theorie. Hamburg: Sabine Groenewold.

Berg, Lawrence D. 2002. (Some) spaces of critical geographies. In, A. Rogers \& H. Viles (eds.), The Student's Guide to Geography, $2^{\text {nd }}$ edition. Oxford: Blackwell.

Blomley, Nicholas. 2006. Uncritical critical geography? Progress in Human Geography 30(1), 87-94.

Blomley, Nicholas. 2008. The spaced of critical geography. Progress in Human Geography, forthcoming.

Blunt, Alison and Jane Wills. 2000. Dissident Geographies: An Introduction to Radical Ideas and Practice. Harlow: Prentice Hall.

Castree, Noel. 2000. Professionalisation, activism, and the university: Whither "critical geography"? Environment and Planning A 32(6), 955-70.

Diop, Cheikh Anta. 1974. The African Origin of Civilization: Myth or Reality. Translated by Mercer Cook. Chicago: L. Hill.

Fuller, Duncan and Rob Kitchin. 2004. Radical Theory/Critical Practice: Making a Difference Beyond the Academy? Kewlona: Praxis (e)Press.

Gibbons, Wendy. 2001. "Critical of what?": Past and current issues in critical human geography. History of Intellectual Culture 1(1). http://www.ucalgary.ca/hic/website/2001 vol1nol/articles/gibbons article 2001.pdf 
Horkheimer, Max and Theodor W. Adorno. 2002/1944. Dialectic of Enlightenment: Philosophical Fragments. Stanford: Stanford University Press.

Johnston, Ron. 2003. Geography and the social science tradition. In, Sarah L. Holoway, Stephen P. Rice \& Gill Vanlentine (eds.), Key Concepts in Geography. London: SAGE, pp. Pp. 51-72.

Kant Immanuel. 2008/1783. Beantwortung der Frage: Was ist Aufkärung? http://gutenberg.spiegel.de

Katz, Cindi. 1998. Lost and found in the posts: Addressing critical human geography. Environment and Planning D: Society and Space 16, 257-278.

Kearns, Gerry. 2004. The political pivot of geography. The Geographical Journal 170(4), 337-46.

Marcuse, Herbert. 1964. One-Dimensional Man: Studies in the Ideology of Advanced Industrial Society. Boston: Beacon Press.

Marx, Karl. 1969/1845. Thesen über Feuerbach. In, Marx-Engels Werke, Band 3. Berlin: Dietz, p. 5-7. www.mlwerke.de

Moss, Pamela, Lawrence Berg and Caroline Debiens. 2002. The political economy of publishing in geography. ACME: An International e-Journal for Critical Geographies 1(1), 1-7. http://www.acme-journal.org/roll/intro.pdf

Peet, Richard. 1998. Modern Geographical Thought. Oxford: Blackwell.

Peet, Richard (ed.). 1977. Radical Geography: Alternative Viewpoints on Contemporary Social Issues. Chicago: Maaroufa Press.

Watts, Michael. 2001. Petro-violence: Community, extraction, and political ecology of a mythic commodity. In, Nancy Lee Peluso \& Michael Watts (eds.), Violent Environments. Ithaca: Cornell University Press, pp. 189-212.

Werlen, Benno. 1999. Zur Ontologie von Gesellschaft und Raum. $2^{\text {nd }}$ ed. Stuttgart: Franz Steiner. 